\title{
Candidate Gene Polymorphisms of Renin Angiotensin System and Essential Hypertension in a South Indian Tamilian Population
}

\author{
P. Ramu ${ }^{\mathrm{a}}$, G. Umamaheswarana, D.G. Shewade ${ }^{\mathrm{a}}$, R.P. Swaminathan ${ }^{\mathrm{b}}$, T.K. Dutta ${ }^{\mathrm{b}}$, \\ J. Balachander ${ }^{c}$ and C. Adithan ${ }^{\mathrm{a}}$ \\ a Pharmacogenomics Laboratory, Department of Pharmacology, JIPMER, \\ Pondicherry 605 006, India \\ ${ }^{b}$ Department of Medicine, 'Department of Cardiology, JIPMER, Pondicherry 605006 , India
}

KEYWORDS Essential Hypertension. Polymorphism. Renin-Angiotensin System

\begin{abstract}
Genetic variants of renin angiotensin system (RAS) gene play a significant role in the pathogenesis of essential hypertension and cardiovascular diseases. In the present study, we investigated the association of RAS gene polymorphisms with hypertension by analyzing the polymorphisms ACE ID, AGT T207M, M268T and AGT1R A1166C in 462 hypertensive patients and 444 healthy subjects. Genotyping was determined by allele specific PCR, PCR-RFLP and RT-PCR Taqman assay. The ACE ID heterozygous (OR=1.5: $95 \% \mathrm{CI}: 1.0-2.3, \mathrm{p}<0.05)$ and $\mathrm{ACE}$ DD homozygous genotype $(\mathrm{OR}=1.7: 95 \% \mathrm{CI}: 1.2-$ $2.8, \mathrm{p}<0.01)$ was found to be significantly associated with hypertension. There was no significant association between $A G T$ T207M, M268T and AGT1R A1166C gene polymorphisms and hypertension. Gender-specific analysis showed ACE ID heterozygous genotypes were positively associated with hypertension among male hypertensives $(\mathrm{OR}=1.9: 95 \% \mathrm{CI}: 1.1-2.6$, $\mathrm{p}<0.01)$. Significant gene-gene interaction was observed between ACE ID and AGT M268T polymorphisms (OR=2.0; 95\% CI: $1.2-3.5, \mathrm{p}<0.01)$. Our results suggest that ACE ID polymorphism is associated with hypertension. Further, gene-gene interaction between ACE ID and AGT M268T gene polymorphisms further modified the risk of essential hypertension.
\end{abstract}

\section{INTRODUCTION}

Essential hypertension $(\mathrm{EH})$ is a polygenic disorder resulting from the interaction of several genetic and environmental factors. EH has been recognized as a major contributing risk factor in several cardiovascular ailments. Renin angiotensin system (RAS) plays an important role in the regulation of blood pressure. Association between candidate gene polymorphisms of RAS and EH has been reported in different populations (Danser and Schunkert 2000).

Genes encoding RAS include angiotensin converting enzyme gene (ACE ID), angiotensinogen gene (AGT T207M and M268T) [previously recognized as AGT T174M and M235T] and angiotensin II type 1 receptor gene (AGT1R A1166C) polymorphisms. About 78 molecular variants of human $A C E$ gene have been reported (Rieder et al. 1999), since the identification of

Correspondencing Author:

Dr. C. Adithan

Pharmacogenomics Laboratory,

Department of Pharmacology,

JIPMER, Pondicherry 605006 , India

Telephone: $91+4132272380$, Extn. 6358

Fax: 91+ 4132279216

E-mail:jipgene@jipmer.edu its gene sequence (Soubrier et al. 1988). Among them, ACE ID polymorphism has been extensively studied in all cardiovascular disorders. The presence or absence of $287 \mathrm{bp}$ in intron 16 of ACE gene leads to insertion/deletion polymorphism (Rigat et al. 1990; Rigat et al. 1992). The presence of deletion allele with elevated serum ACE levels (Rigat et al. 1990; Danser et al. 1995) eventually leads to hypertension (Higaki et al. 2000), myocardial infarction (Cambien et al. 1992), and cardiomyopathy (Rai et al. 2008). Similarly, AGT (Gaillard et al. 1989; Jeunemaitre et al. 1992b) and AGT1R genes were cloned and several molecular variants were identified (Furta et al. 1992; Takayanagi et al. 1992; Bonnardeaux et al. 1994; Ishanov et al. 1997).

Numerous studies have been carried out on the association between $A G T$ T207M and M268T gene polymorphisms and cardiovascular disorders (Ishanov et al. 1997; Pilbrow et al. 2007). Increase in levels of angiotensinogen in T268 homozygous variant leads to increase in blood pressure (Bloem et al. 1997). The AGT M268T polymorphism was found to be in linkage disequilibrium with $\mathrm{T} 207 \mathrm{M}$ and promoter region A -6 G polymorphisms. Haplotype analysis of AGT T207M and M268T revealed a significant association with hypertension among the Caucasian and Taiwan Chinese populations 
(Jeunemaitre et al. 1992a; 1992b; Wang et al. 2002; Wu et al. 1997). Association between C/ $\mathrm{C}$ homozygous variant genotype of AGT1R A $1166 \mathrm{C}$ and increased vasoconstriction in human arteries has been reported by Amant et al.(1997). Various studies on RAS gene polymorphisms in relation to hypertension showed contradictory results across different ethnic populations with both positive and negative results (Higaki et al. 2000; Jeunemaitre et al. 1992; Bonnardeaux et al. 1994; Ashavaid et al. 2000; Bhavani et al. 2004; Randhawa et al. 2006; Nair et al. 2003; Nejatizadeh et al. 2008).

Very few studies have described the association of ACE ID (22-24) and AGT gene (Nair et al. 2003; Nejatizadeh et al. 2008) polymorphisms in relation to $\mathrm{EH}$ among Indian population. Hence, we sought to investigate the association between RAS gene polymorphisms and susceptibility to EH in south Indian Tamilian population. Further, we also investigated the gender specificity and gene-gene interactions of RAS gene polymorphisms in relation to $\mathrm{EH}$. Tamilians are Dravidian people from the Indian sub-continent, living in southern parts of India and north-eastern Sri Lanka. They are ethnically, linguistically and culturally related to other Dravidian people of the sub-continent. An estimated 77 million Tamilians reside in India and other parts of the world (Tamil people 2009).

\section{MATERIALS AND METHODS}

\section{Study Participants}

The study was carried out in 906 ethnically matched unrelated subjects including 462 essential hypertensives ( 228 men and 234 women) and 444 healthy controls (201 men and 243 women) aged 30-60 years. The hypertensive cases were diagnosed and selected from the outpatient clinics of hypertension and internal medicine (JIPMER hospital, Pondicherry, India). All of them were residents of Tamilnadu and Pondicherry for atleast three generations. Patients receiving antihypertensive medications for more than 3 months (or) newly diagnosed hypertensive patients with systolic blood pressure more than $140 \mathrm{mmHg}$ and/or diastolic blood pressure more than $90 \mathrm{mmHg}$ on 2 or more consecutive visits were considered to be hypertensives (European Society of Hypertension-European society of Cardiology Guide- lines, 2003). The age of hypertension is defined as the time when BP recordings fulfilled the inclusion criteria of hypertension on 2 consecutive visits before starting the medication or when antihypertensive medication is initiated. Patients with other significant illnesses that might affect the outcome of investigation e.g., diabetes mellitus, hyperlipidemia, liver or renal disease, congestive cardiac failure and recent episode of myocardial infarction were excluded. Pregnant and lactating women and those receiving medications for other indications that could affect BP were also excluded.

The control group had no personal or family history of hypertension in the first degree relatives with systolic blood pressure less than 130 $\mathrm{mmHg}$ and diastolic blood pressure less than $85 \mathrm{mmHg}$. Patients who visited the outpatient clinics with minor illness without hypertension, diabetes mellitus, hyperlipidemia and family history of hypertension in previous records were recruited as controls. None of the control groups were receiving antihypertensive therapy, treatment for heart disease or hormone replacement therapy during the time of investigation. Plasma lipid profile and blood glucose level were measured after overnight fasting for both hypertensive and normotensive subjects to rule out diabetes and hyperlipidemia. A detailed family history relating to their pedigree was taken to identify if any of the close relatives of the volunteers or patients were hypertensives. Details such as identification characteristics, body weight and height, drug history were recorded. All the participants were interviewed using a standardized questionnaire with regard to their lifestyle, smoking, alcohol consumption and drug intake. In all subjects, height was measured to the nearest centimeter and weight to the nearest $0.1 \mathrm{~kg}$, which was used for calculation of BMI $\left(\mathrm{kg} / \mathrm{m}^{2}\right)$. Blood pressure was measured in the right arm by resting the subjects for 10 minutes and by using standard sphygmomanometer and the average of three readings taken 2 minutes apart was recorded. The study was approved by the institutional ethics committee and written informed consent was obtained from all the participants who opted to participate in this study.

\section{Genotyping Methods}

Five milliliter of venous blood was collected with ethylene diamine tetra acetic acid (EDTA) 
as anticoagulant. The genomic DNA was extracted from the peripheral leucocytes using standard phenol-chloroform extraction method. ACE ID polymorphism was determined by allele specific Polymerase Chain Reaction (PCR) (Tiret et al. 1992). The primers for PCR amplification of ACE ID were 5'-CTGGAGAG CCACTCCCATCCTTTCT-3' (Forward) and 5'-GACGTGGCCATCACATTCGTCAGAT3' (Reverse). The PCR products were run on $2 \%$ agarose gel electrophoresis. The different fragments obtained were 490bp II, 190bp DD, and 490bp and 190bp ID. The samples with homozygous deletion DD by this assay were retyped using a third insertion specific primer 5'-TTTGAGACGGAGTCTCGCTC-3'. This was done to rule out the possibility of mistyping individuals due to preferential amplification of the deletion fragment over the longer insertion fragment (Shanmugam et al. 1993).

AGT T207M and AGT1R A1166C polymorphisms were identified with PCR-RFLP method. The primers used for AGT T207M were 5'-GATGCGCACAAGGTCCTG -3' (Forward) and 5'-CAGGGTGCTGTCCACACT GGCTCGC-3' (Reverse). The amplified 303 bp products were digested with the restriction enzyme NcoI and incubated overnight at $37^{\circ} \mathrm{C}$ (Caufield et al. 1994). The digested products were separated based on their size using $8 \%$ polyacrylamide gel electrophoresis. The different fragments obtained were $303 \mathrm{bp}$ in homozygous wild type TT, 211 and $92 \mathrm{bp}$ in homozygous variant MM and 303, 211 and 92 bp in case of heterozygous variant TM. The primers for AGT1R A1166C polymorphism were 5'-GAAGCCTGCACCATGTTTTGA-3' (Forward) and 5'-GGCTTTGCTTTGTCTT GTTG-3' (Reverse). The amplified 229 bp products were digested with restriction enzyme Dde1 as described earlier (Bonnardeaux et al. 1994) and the digested PCR products were separated by $8 \%$ polyacrylamide gel electrophoresis. The different fragments obtained were $229 \mathrm{bp}$ in homozygous wild type AA, 117 and $112 \mathrm{bp}$ in homozygous variant $\mathrm{CC}$ and 229, 117 and 112 bp in case of heterozygous variant genotype AC. All the heterozygous and homozygous variant genotype samples were genotyped again for confirmatory purpose.

Genotyping for AGT M268T polymorphism was carried out by Real Time Thermocycler (7300 Applied Biosystems) using Taqman SNP genotyping assay with fluorogenic 5' nuclease chemistry to enable the detection of the specific PCR product. The PCR reaction was carried out in duplicate in a $20 \mu \mathrm{L}$ final volume which contained $10 \mu \mathrm{L}$ of Taqman Universal PCR master mix (2X), $0.5 \mu \mathrm{L}$ of $20 \mathrm{X}$ working stock of SNP genotyping assay, $4.5 \mu \mathrm{L}$ of genomic DNA diluted in DNase free water and $5 \mu \mathrm{L}$ of Milli Q water. The allelic discrimination analysis was finally performed with 7300 SDS software.

\section{Statistical Analysis}

Statistical analysis was done using the Statistical Packages for Social Sciences software. (SPSS, Windows version release 13, SPSS Inc., Chicago, Illinois, USA). Demographic details of hypertensive cases and controls that were continuous variables were compared using Student's unpaired $t$-test, whereas dichotomous variables were compared by Chi square and/ or Fisher's exact test. Differences in allele frequencies and genotype distribution between hypertensive cases and controls were compared by Chi square and/or Fisher's exact test. The association between genotypes and hypertension was analysed by calculating the crude odds ratio (OR) and 95\% confidence interval (95\% CI) using Chi square and/or Fisher's exact test. The adjusted OR was calculated using unconditional logistic regression and the low risk genotype was designated as reference category. For analyzing gene-gene interactions, stratified variables were generated and included in the logistic model, simultaneously with appropriate indicator variables. Linkage disequilibrium values for the pair of dimorphisms were measured by using Helix Tree software (Golden helix ${ }^{\mathrm{TM}}$ CA, USA). Haplotypes of AGT T207M and M268T were constructed using the EM algorithm. $\mathrm{P}$ value $<0.05$ was used as the level of significance.

\section{RESULTS}

\section{Demographic Details of Study Subjects}

No significant differences was observed in sex distribution, BMI, heart rate, alcohol consumption, dietary habits, total cholesterol, triglycerides, high density and very low density lipoprotein cholesterol levels (Table 1). The 
Table 1: Demographic details of study subjects

\begin{tabular}{|c|c|c|c|}
\hline Parameter & Hypertensive cases $(n=462)$ & Controls $(n=444)$ & $p$ value \\
\hline Sex M/F & $228 / 234$ & $201 / 243$ & 0.2 \\
\hline Age (Years) & $45.1 \pm 0.4$ & $47.4 \pm 0.4$ & 0.01 \\
\hline BMI $\left(\mathrm{kg} / \mathrm{m}^{2}\right)$ & $23.0 \pm 0.3$ & $22.9 \pm 0.2$ & 0.6 \\
\hline Systolic blood pressure ( $\mathrm{mmHg}$ ) & $153.4 \pm 0.8$ & $117.5 \pm 0.4$ & 0.0001 \\
\hline Diastolic blood pressure ( $\mathrm{mmHg}$ ) & $97.3 \pm 0.5$ & $78.2 \pm 0.3$ & 0.0001 \\
\hline Alcohol users & $124(27)$ & $100(22.5)$ & 0.2 \\
\hline Smokers & $99(21.4)$ & $40(9)$ & 0.001 \\
\hline \multicolumn{4}{|l|}{ Diet } \\
\hline Vegetarian & $423(91.6)$ & $414(93.2)$ & 0.4 \\
\hline Non-vegetarian & $39(8.4)$ & $30(6.8)$ & \\
\hline Total cholesterol (mg / dL) & $176.0 \pm 1.5$ & $173.7 \pm 1.7$ & 0.08 \\
\hline Triglycerides (mg / dL) & $120.8 \pm 2.9$ & $117.9 \pm 2.3$ & 0.2 \\
\hline HDL cholesterol (mg / dL) & $41.0 \pm 0.4$ & $41.0 \pm 0.4$ & 0.6 \\
\hline LDL cholesterol (mg /dL) & $111.5 \pm 1.3$ & $105.4 \pm 1.3$ & 0.01 \\
\hline $\operatorname{VLDL}(\mathrm{mg} / \mathrm{dL})$ & $24.9 \pm 0.5$ & $23.4 \pm 0.5$ & 0.09 \\
\hline
\end{tabular}

Values are mean \pm SEM and numbers and percentage

mean age $(45.1 \pm 0.4$ vs. $47.4 \pm 0.4, p<0.01)$ and smokers $(21.4 \%$ vs. $9 \%, p<0.001)$ were higher in cases when compared to controls. However, there were significant differences in age, SBP, DBP, smoking patterns and lowdensity lipoprotein-cholesterol level between the hypertensive cases and controls. Potential confounders such as age and smoking were taken for multiple logistic regression analysis using suitable indicator variables.

\section{Genotype Distribution of RAS Gene Polymorphisms among Cases and Controls}

The distribution of RAS gene polymorphisms is summarized in Table 2. There was a signifi-

Table 2: RAS gene polymorphisms and essential hypertension among hypertensive cases and controls

\begin{tabular}{|c|c|c|c|c|}
\hline Polymorphism & Cases $(n=462)$ & Controls $(n=444)$ & OR $(95 \%$ CI) & $p$ value \\
\hline \multicolumn{5}{|l|}{$A C E \mathrm{I} / \mathrm{D}$} \\
\hline II & $124(26.8)$ & $153(34.5)$ & 1.0 & 0.05 \\
\hline ID & $211(45.7)$ & $190(42.8)$ & $1.4(1.0-1.9)$ & 0.02 \\
\hline DD & $127(27.5)$ & $101(22.7)$ & $1.5(1.1-2.2)$ & 0.009 \\
\hline \multicolumn{5}{|l|}{ Allele } \\
\hline$D$ & 0.50 & 0.44 & $1.3(1.1-1.5)$ & \\
\hline$I$ & 0.50 & 0.56 & & \\
\hline \multicolumn{5}{|l|}{ AGT T207M } \\
\hline TT & $376(81.4)$ & 354 (79.7) & 1.0 & \\
\hline \multirow{2}{*}{\multicolumn{5}{|c|}{ Allele }} \\
\hline & & & & \\
\hline$T$ & 0.91 & 0.90 & $1.0(0.7-1.3)$ & 0.6 \\
\hline$M$ & 0.09 & 0.10 & & \\
\hline \multicolumn{5}{|l|}{ AGT M268T } \\
\hline MM & $70(15.2)$ & $75(16.9)$ & 1.0 & \\
\hline MT & $164(35.5)$ & $170(38.3)$ & $0.9(0.6-1.4)$ & 0.9 \\
\hline TT & $228(49.3)$ & $199(44.8)$ & $1.2(0.8-1.8)$ & 0.3 \\
\hline \multicolumn{5}{|l|}{ Allele } \\
\hline$M$ & 0.33 & 0.36 & $1.3(0.9-1.4)$ & 0.2 \\
\hline$T$ & 0.67 & 0.64 & & \\
\hline \multicolumn{5}{|l|}{$A T 1 R$ A $1166 \mathrm{C}$} \\
\hline AA & $420(90.9)$ & $399(89.9)$ & 1.0 & \\
\hline$* \mathrm{AC}+\mathrm{CC}$ & $42(9.1)$ & $45(10.1)$ & $0.9(0.6-1.4)$ & 0.7 \\
\hline \multicolumn{5}{|l|}{ Allele } \\
\hline A & 0.95 & 0.95 & $0.9(0.6-1.5)$ & 0.9 \\
\hline$C$ & 0.05 & 0.05 & & \\
\hline
\end{tabular}

Values in parenthesis indicate percentage

*One homozygous variant genotype of AGT T207M and AGT1R A1166C polymorphism in hypertensive cases were combined with heterozygous genotype for analysis. 
Table 3: Gender specific distribution of RAS gene polymorphisms among the study subjects

\begin{tabular}{|c|c|c|c|c|c|c|}
\hline \multirow{2}{*}{$\begin{array}{l}\text { Genes and } \\
\text { Genotypes }\end{array}$} & \multicolumn{3}{|c|}{ Male } & \multicolumn{3}{|c|}{ Female } \\
\hline & $\begin{array}{l}\text { Cases } \\
(n=228)\end{array}$ & $\begin{array}{l}\text { Controls } \\
(n=201)\end{array}$ & $p$ value & $\begin{array}{l}\text { Cases } \\
(n=234)\end{array}$ & $\begin{array}{l}\text { Controls } \\
(n=243)\end{array}$ & $p$ value \\
\hline \multicolumn{7}{|l|}{$A C E$ ID } \\
\hline II & $51(22.4)$ & $66(32.8)$ & & $73(31.2)$ & $87(35.8)$ & \\
\hline ID & $111(48.7)$ & $83(41.3)$ & 0.03 & $100(42.7)$ & $107(44.0)$ & 0.7 \\
\hline DD & $66(28.9)$ & $52(25.9)$ & 0.08 & $61(26.1)$ & $49(20.2)$ & 0.1 \\
\hline \multicolumn{7}{|l|}{$A G T$ T207M } \\
\hline TT & $184(80.7)$ & $157(78.1)$ & & $192(82.1)$ & $197(81.1)$ & \\
\hline *TM+MM & 44 (19.3) & 44 (21.9) & 0.5 & 42 (17.9) & 46 (18.9) & 0.8 \\
\hline \multicolumn{7}{|l|}{ AGT M268T } \\
\hline MM & $30(13.2)$ & $31(15.4)$ & & $36(15.4)$ & $35(14.4)$ & \\
\hline MT & $86(37.7)$ & $83(41.3)$ & 0.4 & $76(32.5)$ & $96(39.5)$ & 0.3 \\
\hline $\mathrm{TT}$ & $112(49.1)$ & $87(43.3)$ & 0.1 & $122(52.1)$ & $112(46.1)$ & 1.0 \\
\hline \multicolumn{7}{|l|}{$A T 1 R$ A $1166 C$} \\
\hline $\mathrm{AA}$ & $210(92.1)$ & $182(90.5)$ & & $210(89.7)$ & $217(89.3)$ & \\
\hline$* \mathrm{AC}+\mathrm{CC}$ & $18(7.9)$ & $19(9.5)$ & 0.6 & $24(10.3)$ & $26(10.7)$ & 0.8 \\
\hline
\end{tabular}

Values in parenthesis indicate percentage

*One homozygous variant genotype of AGT T207M and AGT1R A1166C polymorphism in hypertensive cases were combined with heterozygous genotype for analysis.

cant association between the ACE ID [II vs. ID, $\mathrm{OR}=1.4$ (95\% CI: 1.0-1.9), $p<0.05]$ and DD genotypes and hypertension [II vs. DD, OR= 1.5 (95\% CI: 1.1-2.2), $p<0.02]$. When the association between ACE ID genotype and hypertension was analyzed after adjusting the confounding factors, the risk for hypertension was further increased in ID heterozygous and DD homozygous genotype carriers (Table 4). There were no significant differences in the genotypes and alleles for AGT M268T, T207M and AGT1R A1166C gene polymorphisms between hyper- tensive patients and controls before and after adjusting the confounding factors.

\section{Gender Specific Distribution of RAS Gene Polymorphisms among Cases and Controls}

The frequency of ACE ID heterozygous genotype was higher among male hypertensive patients compared with the control group (48.7\% vs. $41.3 \%, p<0.03)$. The prevalence of the $A C E$ $\mathrm{D}$ allele was higher in male cases when compared to male controls $(53.3 \%$ vs. $46.5 \%, p<$

Table 4: Odds ratio for RAS gene polymorphisms among the study subjects

\begin{tabular}{|c|c|c|c|c|c|c|}
\hline \multirow[t]{2}{*}{ Genotypes } & \multicolumn{2}{|c|}{ All subjects } & \multicolumn{2}{|c|}{ Males } & \multicolumn{2}{|c|}{ Females } \\
\hline & OR (95\% CI) & $p$ value & OR $(95 \% C I)$ & $p$ value & OR $(95 \% \mathrm{CI})$ & $p$ value \\
\hline \multicolumn{7}{|l|}{$A C E$ ID } \\
\hline II & 1.0 & & 1.0 & & 1.0 & \\
\hline ID & $1.5(1.0-2.3)$ & 0.05 & $1.9(1.1-2.6)$ & 0.01 & $1.1(0.7-1.7)$ & 0.8 \\
\hline DD & $1.7(1.2-2.8)$ & 0.01 & $1.6(1.0-2.8)$ & 0.06 & $1.6(0.9-2.5)$ & 0.1 \\
\hline \multicolumn{7}{|l|}{$A G T$ T207M } \\
\hline TT & 1.0 & & 1.0 & & 1.0 & \\
\hline *TM+MM & $1.0(0.7-1.3)$ & 0.6 & $0.9(0.5-1.4)$ & 0.4 & $0.9(0.5-1.5)$ & 0.6 \\
\hline \multicolumn{7}{|l|}{$A G T \mathrm{M} 268 \mathrm{~T}$} \\
\hline MM & 1.0 & & 1.0 & & 1.0 & \\
\hline MT & $1.1(0.8-1.7)$ & 0.8 & $1.1(0.6-1.9)$ & 0.1 & $0.8(0.5-1.4)$ & 0.3 \\
\hline $\mathrm{TT}$ & $1.3(0.9-2.1)$ & 0.2 & $1.4(0.7-2.4)$ & 0.2 & $1.0(0.7-1.7)$ & 0.8 \\
\hline \multicolumn{7}{|l|}{$A T 1 R$ A $1166 \mathrm{C}$} \\
\hline AA & 1.0 & & 1.0 & & 1.0 & \\
\hline$* \mathrm{AC}+\mathrm{CC}$ & $1.0(0.5-1.9)$ & 0.9 & $0.7(0.4-1.6)$ & 0.3 & $1.0(0.5-1.9)$ & 1.0 \\
\hline
\end{tabular}

Values in parenthesis indicate percentage (Table 3)

Odds ratio and $\mathrm{p}$ value adjusted for confounding factors such as smoking in males and age in females.

*One homozygous variant genotype in AGT T207M and AGT1R A1166C were combined with heterozygous genotype for analysis. 
Table 5: Gene-gene interaction of RAS gene polymorphisms among cases and controls

\begin{tabular}{|c|c|c|c|c|}
\hline Genotypes & $\begin{array}{l}\text { Cases } \\
(n=462)\end{array}$ & $\begin{array}{l}\text { Controls } \\
(n=444)\end{array}$ & OR $(95 \%$ CI) & $p$ value \\
\hline \multicolumn{5}{|l|}{ ACE ID \& AGT T207M } \\
\hline$A C E$ II \& AGT TT & $108(23.4)$ & $128(28.8)$ & 1.0 & \\
\hline$A C E$ II \& AGT TM or MM & $23(5.0)$ & $34(7.7)$ & $0.7(0.5-134)$ & 0.6 \\
\hline$A C E$ ID or DD \& AGT TT & $265(57.3)$ & $226(50.9)$ & $1.4(0.9-2.1)$ & 0.08 \\
\hline $\begin{array}{l}A C E \text { ID or DD \& } A G T \mathrm{TM} \text { or } \mathrm{MM} \\
A C E \text { ID \& } A G T \text { M } 268 \mathrm{~T}\end{array}$ & \multicolumn{3}{|c|}{$A C E$ ID \& AGT M268T } & 0.2 \\
\hline ACE II \& AGT MM & $19(4.1)$ & $27 \quad(6.1)$ & 1.0 & \\
\hline$A C E$ II \& AGT MT/TT & $104(22.5)$ & $135(30.4)$ & $1.1(0.6-2.1)$ & 0.9 \\
\hline$A C E$ ID or DD \& AGT MM & $49(10.6)$ & $48(10.8)$ & $1.4(0.6-2.8)$ & 0.3 \\
\hline$A C E$ ID or DD \& AGT MT or TT & $290(62.8)$ & $234(52.7)$ & $2.0(1.2-3.5)$ & 0.01 \\
\hline \multicolumn{5}{|l|}{$A C E$ ID \& $A T 1 R$ A $1166 \mathrm{C}$} \\
\hline$A C E$ II \& AT1R CC & $113(24.5)$ & $136(30.6)$ & 1.0 & \\
\hline$A C E$ II \& AT1R AC or CC & $13(2.8)$ & $16 \quad(3.6)$ & $1.0(0.5-2.1)$ & 0.7 \\
\hline$A C E$ ID or DD \& AT1R AA & $300(64.9)$ & $263(59.2)$ & $1.4(0.98-1.9)$ & 0.08 \\
\hline$A C E$ ID or DD \& AT1R AC or CC & $36(7.8)$ & $29(6.5)$ & $1.5(0.9-2.6)$ & 0.2 \\
\hline
\end{tabular}

Values in parenthesis indicate percentage.

Odds ratio and $\mathrm{p}$ value adjusted for confounding factors age, smoking and genotypes.

0.06) whereas there was no significant association between AGT T207M, M268T and AGT1R A1166C gene polymorphisms and hypertension among the male and female cases and controls (Table 3).

Values of some confounding factors were higher in male hypertensive patients compared with male controls, including smoking (43.4\% vs. $20 \%, p<0.001)$ and LDL cholesterol (112.5 \pm 1.4 vs. $107.4 \pm 1.3, p<0.01)$. Age was higher in female controls than in female cases $(46.8 \pm$ 0 . vs. $43.4 \pm 0.5, p<0.01)$. These confounding factors were adjusted by multiple logistic regression analysis to calculate the adjusted odds ratio as shown in Table 4 . When the association between the hypertensive risk and RAS genotypes was analysed, ID genotype of ACE was significantly associated with hypertension among male subjects [II vs. ID; $\mathrm{OR}=1.9 ; 95 \% \mathrm{CI}$ : $1.1-2.6, p<0.01)]$. There was no significant difference in the genotype and allelic distribution of AGT M268T, T207M and AGT1R A1166C gene polymorphisms amongst the male and female cases and controls even after adjusting the confounding variables.

\section{Gene-gene Interaction of RAS Gene Polymorphisms}

The high risk genotypes (heterozygous and homozygous variants) of RAS gene polymorphisms were investigated by comparing them with no risk genotypes (wild-type reference genotype) for gene-gene interaction. Individuals carrying the combination of both heterozy- gous and homozygous variant genotypes of $A C E$ ID and AGT M268T were found to have a twofold higher risk for hypertension (Table 5). The risk was not significant between the combinations of other gene polymorphisms and hypertension among the cases and controls (Table 6).

\section{Haplotypes of AGT (M268T and T207M) Gene Polymorphisms}

The two polymorphisms, AGT T207M and M268T were found to be in weak linkage disequilibrium (LD correlation, $\mathrm{r}$ value $=0.9, p<$ 0.07). Four different haplotypes were constructed as shown in Table 7. The haplotype frequencies were almost equally distributed and did not differ significantly among cases and controls.

\section{DISCUSSION}

Cardiovascular disorders resulted in 2.3 million deaths in the year 1990 and are expected to be doubled by the year 2020. Hypertension accounts for 1.2 million deaths due to coronary heart disease and 0.5 million deaths due to stroke in India (Gupta et al. 2004). The present study is the largest case-control study to describe the role of RAS gene polymorphisms and susceptibility to $\mathrm{EH}$ in any of the Indian population.

When the influence of all the three genes (4 SNPs) were analyzed separately, the ACE ID heterozygous and homozygous DD genotype of $A C E$ gene were found to be associated with 
Table 6: Gene-gene interactions (three way) of ACE ID, AGT M268T, T207M and AT1R A1166C genotypes on hypertension risk

\begin{tabular}{|c|c|c|c|c|}
\hline Genotypes & $\begin{array}{l}\text { Cases } \\
(n=462)\end{array}$ & $\begin{array}{l}\text { Controls } \\
(n=444)\end{array}$ & $O R^{a}(95 \% C I)$ & $p$ value \\
\hline \multicolumn{5}{|l|}{ ACE ID, AGT T207M \& M268T } \\
\hline II, TT \& MM & 20 & 24 & 1.0 & \\
\hline II, TT \& MT or TT & 101 & 122 & $1.3(0.6-2.8)$ & 0.6 \\
\hline II, TM or MM \& MM & 3 & 3 & $1.1(0.2-7.8)$ & 0.8 \\
\hline II, TM or MM \& MT or TT & 12 & 13 & $1.0(0.3-3.2)$ & 0.9 \\
\hline ID or DD ,TT \& MM & 38 & 41 & $1.5(0.6-3.3)$ & 0.5 \\
\hline ID or DD, TT \& MT or TT & 255 & 212 & $2.0(1.0-4.1)$ & 0.09 \\
\hline ID or DD, TM or MM \& MM & 7 & 7 & $1.3(0.3-5.1)$ & 0.7 \\
\hline ID or DD, TM or MM \& MT or TT & 26 & 22 & $2.1(0.8-5.1)$ & 0.1 \\
\hline \multicolumn{5}{|l|}{$A C E \mathrm{ID}, A T 1 R$ A1166C \& AGT T207M } \\
\hline II, AA \& TT & 103 & 116 & 1.0 & \\
\hline II, AA \& TM or MM & 22 & 30 & $0.7(0.4-1.5)$ & 0.8 \\
\hline II, AC or CC \& TT & 10 & 12 & $0.8(0.3-2.2)$ & 0.8 \\
\hline II, AC or CC \& TM or MM & 2 & 4 & $0.7(0.2-4.0)$ & 0.9 \\
\hline ID or DD, AA \& TT & 237 & 205 & $1.5(1.0-2.1)$ & 0.06 \\
\hline ID or DD, AA \& TM or MM & 54 & 48 & $1.5(0.9-2.4)$ & 0.1 \\
\hline ID or DD, AC or CC \& TT & 27 & 22 & $1.6(0.8-3.1)$ & 0.3 \\
\hline ID or $\mathrm{DD}, \mathrm{AC}$ or $\mathrm{CC} \& \mathrm{TM}$ or $\mathrm{MM}$ & 7 & 7 & $1.0(0.3-3.2)$ & 0.6 \\
\hline \multicolumn{5}{|l|}{ ACE ID, AT1R A1166C \& AGT M268T } \\
\hline II, AA \& MM & 19 & 24 & 1.0 & \\
\hline II, AA \& MT or TT & 108 & 122 & $1.3(0.6-2.8)$ & 0.7 \\
\hline II, AC or CC \& MM & 2 & 3 & $1.1(0.2-7.8)$ & 0.9 \\
\hline II, AC or CC \& MT or TT & 10 & 13 & $1.0(0.3-3.2)$ & 0.7 \\
\hline ID or DD, AA \& MM & 38 & 41 & $1.5(0.6-3.3)$ & 0.5 \\
\hline ID or DD, AA \& MT/TT & 255 & 212 & $2.0(1.0-4.1)$ & 0.04 \\
\hline ID or $\mathrm{DD}, \mathrm{AC}$ or $\mathrm{CC} \& \mathrm{MM}$ & 7 & 7 & $1.3(0.3-5.1)$ & 0.8 \\
\hline ID or DD, AC or CC \& MT or TT & 23 & 22 & $2.1(0.8-5.1)$ & 0.1 \\
\hline
\end{tabular}

adds ratio adjusted for age, smoking and other genotypes

hypertension whereas there was no association between AGT T207M, M268T and AGT1R A1166C gene polymorphisms and hypertension. Interestingly, I/D heterozygous genotype was found to be significantly associated with hypertension in men, but not in women. Previous studies on ACE ID gene polymorphism in the Indian population showed a significant association with DD genotype and diastolic blood pressure in men (Bhavani et al. 2004), whereas another study did not show such association with DD genotype in hypertensive men (Ashavaid et al. 2000). In the present study, mean difference in blood pressure and resting heart rate could not be evaluated among the different genotype groups since many of our hypertensive subjects were on antihypertensive medication. When the effect of RAS gene polymorphisms on blood pressure was analyzed in newly diagnosed hypertensive subjects alone, significant differences were not observed among the different genotype groups. The observed differences in the results of our study and previous Indian study may be due to difference in the selection of study subjects (Bhavani et al. 2004). We have excluded the subjects with diabetes mellitus, family history of hypertension, and patients with other cardiovascular disorders whereas their study included the confounding risk factors of hypertension (Bhavani et al. 2004). However, our results are similar with the Japanese (Higaki et al. 2000), Indians (Bhavani et al. 2005), Turkish study (Agachan et al. 2003), African-Americans (Duru et al. 1994) and Framingham heart study (O'Donnell et al. 1998). Earlier, it was proposed that subjects homozygous for deletion DD

Table 7: Haplotypes of AGT T207M and M268T gene polymorphism

\begin{tabular}{lcccc}
\hline Haplotypes & Cases $(n=924)$ & Controls $(n=888)$ & OR $(95 \%$ CI $)$ & $p$ value \\
\hline T, M & $560(60.6)$ & $512(57.6)$ & $0.9(0.7-1.1)$ & 1.0 \\
M, M & $272(29.4)$ & $286(32.2)$ & $1.1(0.8-1.5)$ & 0.4 \\
T, T & $76(8.2)$ & $64(7.2)$ & $0.6(0.3-1.2)$ & 0.7 \\
M, T & $16(1.7)$ & $26(3.0)$ & & 0.1 \\
\hline
\end{tabular}

Values in parenthesis indicate percentage. 
genotypes had higher ACE levels and heterozygous ID subjects had intermediate ACE levels (Rigat et al. 1990; Martinez et al. 2000). But studies also showed negative association between ACE genotypes and ACE levels (Jeunemaitre et al. 1992a). Association between AGT T207M and M268T polymorphisms with hypertension was first explained by Jeunemaitre et al. (1992b) and later on, studies among different ethnic groups showed association between M268T polymorphism and increased plasma angiotensinogen levels in $\mathrm{T}$ allele carriers with hypertension (Bloem et al. 1997; Caulfield et al. 1994; Caulfield et al. 1995; Paillard et al. 1999). A meta analysis by Staessan et al. (1997) comprising 69 studies have shown that the presence of T268 allele was associated with increased risk of hypertension in Caucasians but not in Africans-Africans and Asians. Nejatizadeh et al. (2008) reported a positive association between AGT T268 allele and hypertension in a North Indian population. Contrary to the previous report, a study conducted by Nair et al. in western Indians failed to find association between M268T polymorphism and hypertension and the results are similar with our study (Nair et al. 2003). The genotype and allelic distribution of AGT T207M did not show significant difference with hypertension and the results of our study are consistent with Indians (Nair et al. 2003; Nejatizadeh et al. 2008), Caucasians (Caulfield et al. 1994) and Russians (Mustafina et al. 2002). In the present study, we could not observe any significant association between AGT1R A1166C gene polymorphism and hypertension. A case-control study by Bonnardeaux et al. showed significant association between A1166C polymorphism and hypertension in Caucasians (Bonnardeaux et al. 1994). Later, similar results were reported (Dzida et al. 2001). However, our results are in agreement with the other studies reported in Indians (Ashavaid et al. 2000), and Chinese population (Liu et al. 2002) that did not show significant association between A1166C polymorphism and hypertension.

Hypertension is a polygenic disease and its genetic susceptibility is influenced by multiple gene polymorphisms. Polymorphisms of individual genes may impart susceptibility to a small extent and it is likely that multiple genes are involved in its pathogenesis (Williams et al. 2000; Porto et al. 2003). Many studies have described the association of these polymorph- isms with hypertension on the basis of single locus. However, these studies have not explained the association with multiple gene-gene interaction. Therefore, we analyzed the RAS genes to determine whether genotypes in combination alter the hypertension susceptibility. The present study observed a significant association between the combinations of ACE ID and AGT M268T gene polymorphisms whereas a study by Nair et al. (2003) did not find significant interaction between $A C E$ ID and AGT M268T polymorphism in Indian subjects. It was earlier explained that both the polymorphisms AGT T207M and M268T were in complete linkage disequilibrium and the haplotype combinations of variant alleles were higher in hypertensive cases when compared to controls (Jeunemaitre et al. 1992a). In the present study, both the polymorphisms were found to be in weak linkage disequilibrium. Haplotype combinations of AGT 207T and $268 \mathrm{~T}$ were found to be higher in hypertensive cases as compared to controls in North Indians (Nejatizadeh et al. 2008). However, there were no differences in the haplotypes constructed in our study. The strength of our study includes strict selection of unrelated cases and controls in a homogenous population. The study would have been strengthened with the measurements of circulating ACE and AGT level for genotypephenotype correlation.

To conclude, the present study showed a significant association between ACE ID polymorphism and hypertension. However, such association was not observed for AGT T207M, M268T and AGT1R A1166C gene polymorphisms. The findings of our study deviated from other Indian studies and other populations. This may be due to the presence of unidentified or other important polymorphisms in the RAS gene, difference in selection of study subjects and influence of environmental factors. The present study results imply that ACE ID polymorphism is a predisposing factor for hypertension. Further, the risk was modified with the combined effects of ACE ID and AGT M268T variant genotypes (gene-gene interaction) which resulted in significantly increased risk to hypertension.

\section{ACKNOWLEDGEMENT}

The study was funded by Department of Biotechnology, New Delhi.

(Ref No: D.O.No.BT/PR4076/Med/12/163/ 2003 dated 1/12/2004. 


\section{REFERENCES}

Amant C, Hamon M, Bauters C, Richard F, Helbecque N et al 1997. The angiotensin II type 1 receptor gene polymorphism is associated with coronary artery vasoconstriction. J Am Coll Cardiol, 29(3): 486-490.

Agachan B, Isbir T, Yilmaz H, Akoglu E 2003. Angiotensin converting enzyme I/D angiotensinogen T174MM235T and angiotensin II type 1 receptor A1166C gene polymorphisms in Turkish hypertensive patients. Exp Mol Med, 35(6): 545-549.

Ashavaid TF, Shalia KK, Nair KG, Dalal JJ 2000. ACE and AT1R gene polymorphisms and hypertension in Indian population. J Clin Lab Anal, 14(5): 230-237.

Bhavani BA, Padma T, Sastry BKS, Reddy KN 2004. Gender specific association of insertion/deletion polymorphism of the human angiotensin converting enzyme gene with essential hypertension. Int J Hum Genet, 4(3): 207-213

Bhavani BA, Padma T, Sastry BKS, Reddy KN, Nausheen K 2005. The insertion/deletion polymorphism of angiotensin-converting enzyme (ACE) gene increase the susceptibility to hypertension and / or diabetes. Int $J$ Hum Genet, 5(4): 247-252.

Bloem LJ, Foroud TM, Ambrosius WT, Hanna MP, Tewksbury DA et al. 1997. Association of the angiotensinogen gene to serum angiotensinogen in blacks and whites. Hypertension, 29(5): 1078-1082.

Bonnardeaux A, Davies E, Jeunemaitre X, Fery I, Charru A et al. 1994. Angiotensin II type 1 receptor gene polymorphisms in human essential hypertension. Hypertension, 24(1): 63-69.

Cambien F, Poirier O, Lecerf L, Evans A, Cambou JP et al. 1992. Deletion polymorphism in the gene for angiotensin-converting enzyme is a potent risk factor for myocardial infarction. Nature, 359: 641-644.

Caulfield M, Lavender P, Farrall M, Munroe P, Lawson M et al. 1994. Linkage of the angiotensinogen gene to essential hypertension. New Engl J Med, 330(23): 1629-1633.

Caulfield M, Lavender P, Newell-Price J, Farall M, Kamdar $\mathrm{S}$ et al. 1995. Linkage of the angiotensinogen gene locus to human essential hypertension in African Caribbeans. $J$ Clin Invest, 96(2): 687-692.

Danser AH, Schalekamp MA, Bax WA, van den Brink AM, Saxena PR et al. 1995. Angiotensin-converting enzyme in the human heart. Effect of the deletion/insertion polymorphism. Circulation, 92(6): 1387-1398.

Danser AH, Schunkert H 2000. Renin-angiotensin system gene polymorphisms: Potential mechanisms for their association with cardiovascular diseases. Eur $J$ Pharmacol, 410(2-3): 303-316.

Duru K, Farrow S, Wang JM, Lockette W, Kurtz T 1994. Frequency of a deletion polymorphism in the gene for angiotensin converting enzyme is increased in AfricanAmericans with hypertension. Am J Hypertens, 7(8): 759-762.

Dzida G, Sobstyl J, Puzniak A, Golon P, Mosiewicz J et al. 2001. Polymorphisms of angiotensin-converting enzyme and angiotensin II receptor type 1 genes in essential hypertension in a Polish population. Med Sci Monit, 7(6): 1236-41.

European Society of Hypertension-European Society of Cardiology 2003. Guidelines for the management of arterial hypertension. J Hypertens, 21: 1011-1053.

Furuta H, Guo DF, Inagami T 1992. Molecular cloning and sequencing of the gene encoding human angiotensin II type 1 receptor. Biochem Biophys Res Commun, 183(1): 8-13.

Gaillard I, Clauser E, Corvol P 1989. Structure of the human angiotensinogen gene. DNA, 8(2): 87-99.

Gupta R 2004. Trends in hypertension epidemiology in India. J Hum Hypertens, 18(2): 73-78.

Higaki J, Baba S, Katsuya T, Sato N, Ishikawa K et al. 2000. Deletion allele of angiotensin-converting enzyme gene increases risk of essential hypertension in Japanese men: The Suita Study. Circulation, 101(17): 2060-2065.

Ishanov A, Okamoto H, Yoneya K, Watanabe M, Nakagawa I et al. 1997. Angiotensinogen gene polymorphism in Japanese patients with hypertrophic cardiomyopathy. Am Heart J, 133(2): 184-189.

Jeunemaitre X, Lifton RP, Hunt SC, Williams RR, Lalouel JM 1992a. Absence of linkage between the angiotensin converting enzyme locus and human essential hypertension. Nat Genet, 1(1): 72-75.

Jeunemaitre X, Soubrier F, Kotelevtsev YV, Lifton RP, Williams CS et al. 1992b. Molecular basis of human hypertension: role of angiotensinogen. Cell, 71(1): 169180.

Liu Y, Zhuoma C, Shan G, Cui C, Hou S et al. 2002. A1166C polymorphism of the angiotensin II type 1 receptor gene and essential hypertension in Han, Tibetan and $\mathrm{Yi}$ populations. Hypertens Res, 25(4): 515-21.

Martinez E, Puras A, Escribano J, Sanchis C, Carrion L et al. 2000. Angiotensin-converting enzyme (ACE) gene polymorphisms, serum ACE activity and blood pressure in a Spanish-Mediterranean population. J Hum Hypertens, 14(2): 131-135.

Mustafina OE, Nasibullin TR, Khusnutdinova EK 2002. Association of the T174M polymorphism of the angiotensinogen gene with essential hypertension in Russians and Tatars from Bashkortostan. Mol Biol (Mosk), 36: 599-604.

Nair KG, Shalia KK, Ashavaid TF, Dalal JJ 2003. Coronary heart disease, hypertension, and angiotensinogen gene variants in Indian population. J Clin Lab Anal, 17(5): 141-146.

Nejatizadeh A, Kumar R, Stobdan T, Goyal AK, Gupta M et al. 2008. Significance of angiotensinogen gene haplotypes and genotypes combination in hypertension. J Hypertens, 26(6): 1094-1101.

O’Donnell CJ, Lindpaintner K, Larson MG, Rao VS, Ordovos JM et al. 1998. Evidence for association and genetic linkage of the angiotensin-converting enzyme locus with hypertension and blood pressure in men but not women in the Framingham heart study. Circulation, 97: 17661772 .

Paillard F, Chansel D, Brand E, Benetos A, Thomas F et al. 1999. Genotype-phenotype relationships for the reninangiotensin-aldosterone system in a normal population. Hypertension, 34(3): 423-429.

Pilbrow AP, Palmer BR, Frampton CM, Yandle TG, Troughton RW et al. 2007. Angiotensinogen M235T and T174M gene polymorphisms in combination doubles the risk of mortality in heart failure. Hypertension, 49(2): 322-327.

Porto PI, Garcia SI, Dieuzeide G, Gonzalez C, Pirola CJ 2003. Renin-angiotensin-aldosterone system loci and multilocus interactions in young-onset essential hypertension. Clin Exp Hypertens, 25(2): 117-30.

Rai TS, Dhandapany PS, Ahluwalia TS, Bhardwaj M, Bahl 
A et al. 2008. ACE I/D polymorphism in Indian patients with hypertrophic cardiomyopathy and dilated cardiomyopathy. Mol Cell Biochem, 311(1-2): 67-72.

Randhawa NK, Kumar A, Matharoo K, Bhanwer AJS 2006. Association study of angiotensin-converting enzyme ins/ del polymorphism with hypertension in Punjabi population. Int J Hum Genet, 6(4): 317-321.

Rieder MJ, Taylor SL, Clark AG, Nickerson DA 1999. Sequence variation in the human angiotensin converting enzyme. Nat Genet, 22(1): 59-62.

Rigat B, Hubert C, Alhenc-Gelas F, Cambien F, Corvol P et al. 1990. An insertion/deletion polymorphism in the angiotensin I-converting enzyme gene accounting for half the variance of serum enzyme levels. J Clin Invest, 86(4): 1343-1346.

Rigat B, Hubert C, Corvol P, Soubrier F 1992. PCR detection of the insertion/deletion polymorphism of the human angiotensin converting enzyme gene (DCP1) (dipeptidyl carboxypeptidase 1). Nucleic Acids Res, 20(6): 1433.

Shanmugam V, Sell KW, and Saha BK 1993. Mistyping ACE heterozygotes. PCR Methods Appl, 3(2): 120-121.

Soubrier F, Alhenc-Gelas F, Hubert C, Allegrini J, John M et al. 1988. Two putative active centers in human angiotensin I-converting enzyme revealed by molecular cloning. Proc Natl Acad Sci U S A, 85(24): 9386-9390.

Staessan JA, Wang JG, Ginocchio G, Petrov V, Saavedra AP et al. 1997. The deletion/insertion polymorphism of the angiotensin converting enzyme gene and cardiovascular-renal risk. J Hypertens, 15: 1579-92.

Takayanagi R, Ohnaka K, Sakai Y, Nakao R, Yanase T et al. 1992. Molecular cloning, sequence analysis and expression of a cDNA encoding human type-1 angiotensin II receptor. Biochem Biophys Res Commun, 183(2): 910-916.

Official Home Page of Wikipedia for Tamil people. From $<$ http:/en.wikipedia.org/wiki/Tamil_people> (Retreived Febrauary 3, 2009).

Tiret L, Rigat B, Visvikis S, Breda C, Corvol P et al. 1992. Evidence, from combined segregation and linkage analysis, that a variant of the angiotensin I-converting enzyme (ACE) gene controls plasma ACE levels. Am J Hum Genet, 51(1): 197-205.

Wang JH, Lin CM, Wang LS, Lai NS, Chen DY et al. 2002. Association between molecular variants of the angiotensinogen gene and hypertension in Amis tribes of eastern Taiwan. J Formos Med Assoc, 101(3): 183188.

Williams SM, Addy JH, Philips JA, Dai M, Kpodonu J et al. 2000. Combination of variations in multiple genes are associated with hypertension. Hypertension, 36: 2-6.

Wu SJ, Chiang FT, Chen WJ, Liu PH, Hsu KL et al. 2004. Three single- nucleotide polymorphisms of the angiotensinogen gene and susceptibility to hypertension: single locus genotype vs. haplotype analysis. Physiol Genomics, 17(2): 79-86. 